удК 349.6

DOI https://doi.org/10.32837/pyuv.v0i4.623

\author{
H. Я. Шnapuк \\ orcid.org/0000-0002-6660-4881 \\ кандидат юридичних наук, \\ доцент кафедри соиіального права \\ Львівського національного університету імені Івана Франка
}

\title{
ПРОБЛЕМИ ТА ПЕРСПЕКТИВИ ПРАВОВОГО РЕГУ ЛЮВАННЯ ПОВОДЖЕННЯ З ДИКИМИ ТВАРИНАМИ В УКРАЇНІ
}

Тварини згідно зі ст. 180 Цивільного кодексу України [1] є особливим об'єктом цивільних прав. На них поширюється правовий режим речі, крім випадків, встановлених законом. Правила поводження 3 тваринами встановлюються, зокрема, Законами України «Про тваринний світ» [2], «Про захист тварин від жорстокого поводження» [3] та іншими. Однак тварини як об'єкт тваринного світу є також об'єктом еколого-правового регулювання.

Проблеми правового регулювання захисту тварин від жорстокого поводження розглядалися в працях таких українських вчених, як I.М. Берегеля, O.І. Буткевич, I.А. Головко, I.А. Городецька, Н.I. Зубченко, К.Р. Короткий, Л.Д. Нечипорук, М.В. Пашковська, А.С. Славко, В.О. Турська, В.В. Шеховцов, О.О. Шуміло. Водночас у законодавстві України продовжує існувати низка прогалин, які суттєво впливають на застосування відповідних норм щодо поводження з тваринами на практиці. Викладення цих питань і $є$ метою нашого дослідження.

Три роки тому в Україні почало діяти нове законодавство у сфері поводження з тваринами, яке встановлюе, зокрема, жорсткіші види покарання за неналежне або ж жорстоке поводження з тваринами. Йдеться про два закони, що набули чинності у 2017 році, а саме Закон України «Про внесення змін до деяких законодавчих актів України щодо запровадження гуманного ставлення до тварин» [4] і Закон України «Про внесення змін до деяких законодавчих актів України щодо виконання Конвенції про охорону дикої флори й фауни й природних середовищ існування в Європі» [5].

Перший закон розширив законодавче трактування жорстокого поводження 3 тваринами й збільшив санкції адміністративної та кримінальної відповідальності за правопорушення в цій сфері. Так, якщо раніше за жорстоке поводження 3 тваринами, їх мордування або вчинення інших дій, що призвели до їх мучення чи каліцтва, було передбачено штраф у розмірі від 153 до 357 грн, то тепер він становить від 3400 до 5 100. А санкція ст. 299 Кримінального кодексу [6] починалася одразу ж з арешту, хоча згодом iї доповнили [7] санкцією у вигляді штрафу від 1051000 до 3153000 грн (у перерахунку станом на 01 січня 2020 року). Такий стан речей правильний і доцільний, враховуючи зарубіжний досвід і міжнародні зобов'язання України, а також необхідність посилення охорони тваринного світу зі сторони держави.

Законом України «Про внесення змін до деяких законодавчих актів України щодо виконання Конвенції про охорону дикої флори й фауни й природних середовищ існування в Європі» затверджено доповнення до ст. 63 Закону «Про тваринний світ», які дозволяють Кабінету Міністрів України затверджувати розмір компенсації за незаконне добування, знищення або пошкодження видів тварин. Крім того, передбачено збільшення розміру штрафів у 10 разів за порушення ст. ст. 87 , 88, 88-2 Кодексу про адміністративні правопорушення [8] (далі - КУпАП), які регламентують охорону флори й фауни. Водночас до ст. 88-1 цього Кодексу, яка передбачає відповідальність за порушення порядку придбання чи збуту об'єктів тваринного або рослинного світу, правил утримання диких тварин у неволі або в напіввільних умовах, 3 якихось причин зміни не пропонувалися. Хоча в такій сфері випадків неналежного виконання законодавства достатньо. Адже часто в засобах масової інформації або соціальних мережах можна прочитати про невдоволення людей, яке викликане утриманням диких тварин у неналежних умовах (маленькі клітки, погані умови утримання, непрофесійний персонал тощо). Ще гіршою стає ситуація, якщо ці тварини завдають шкоди майну або здоров'ю людей, які знаходилися поряд із кліткою дикої тварини.

Водночас з єдиного державного реєстру судових рішень можна зробити висновок, що за цією статтею часто притягають до відповідальності осіб, які до прикладу продають на міських ринках рибу без відповідних документів, що засвідчують законність придбання риби, чим порушується вимога ст. 7 Закону України «Про тваринний світ» та п. 3.14 Правил любительського й спортивного рибальства [9]. Звісно, продаж риби невідомого походження теж може спричинити захворювання в людей, чим порушує їхнє право на якісну їжу, тому контроль за якістю продуктів споживання та притягнення до відповідальності винних осіб важливий зі сторони держави. 
Але візьмемо за приклад цікавішу ситуацію, коли особа утримує ведмедя в приватному сектоpi. В Україні поширений лише один вид цих тварин, а саме ведмідь бурий (Ursus arctos), що занесений до Червоної книги України з 2003 року, а також до Червоного списку Міжнародного союзу охорони природи, CITES, і як вид, що підлягає особливій охороні, до Бернської конвенції. Природоохоронний статус виду: Зникаючий. Правила утримання диких тварин, що занесені до Червоної книги України, регулюються Законом України «Про Червону книгу України» [10]. Законність набуття в приватну власність об'єктів Червоної книги України повинна бути підтверджена відповідними документами. Відповідно до ст. 19 цього закону спеціальне використання (добування, збирання) об'єктів Червоної книги України здійснюється у виняткових випадках лише в наукових і селекційних цілях, в тому числі для розмноження, розселення та розведення в штучно створених умовах, а також для відтворення популяцій за дозволом центрального органу виконавчої влади, що реалізує державну політику у сфері охорони навколишнього природного середовища, на підставі рішень Національної комісії з питань Червоної книги України, прийнятих відповідно до ії повноважень.

Спеціальне використання (добування, збирання) об'єктів Червоної книги України з метою отримання прибутку забороняється. Порядок видачі й форма дозволів на спеціальне використання (добування, збирання) об'єктів Червоної книги України визначаються центральним органом виконавчої влади, що забезпечує формування державної політики у сфері охорони навколишнього природного середовища, тобто Міністерством захисту довкілля та природних ресурсів України (далі - Міндовкілля).

Крім того, відповідно до ст. 7 Закону України «Про тваринний світ» законність набуття в приватну власність об'єктів тваринного світу (крім добутих у порядку загального використання) повинна бути підтверджена відповідними документами, що засвідчують законність вилучення цих об'єктів із природного середовища, ввезення в Україну з інших країн, факту купівлі, обміну, отримання в спадок тощо, які видаються в установленому законодавством порядку.

Згідно з п. 3.1. Наказу Мінагрополітики від 13 жовтня 2010 року №643 «Про затвердження Правил використання тварин у видовищних заходах" [11], утримання великих диких тварин (до яких відноситься бурий ведмідь) допускається лише в спеціалізованих закладах (зоопарк, цирк тощо). Утримання диких тварин у неволі допускається за наявності дозволу, що видається центральним органом виконавчої влади з питань охорони навколишнього природного середовища.
Таким чином, щодо бурого ведмедя поширюється особливий правовий режим охорони, суть якого полягає як у необхідності отримання всіх належних документів на право власності на його утримання, так і в умовах утримання, забезпеченні техніки безпеки, належних розмірів вольєру, систематичних ветеринарних оглядах, наявності кваліфікованого персоналу, який умітиме поводитися із цією дикою твариною, годувати її та охороняти.

Крім того, виникає запитання стосовно мети утримання такого виду тварин, як ведмідь, у ресторанних чи інших приватних комплексах, адже отримання прибутку (в тому числі використання ведмедя в рекламних цілях) у цій ситуації заборонено законом, а інша мета виглядає сумнівною.

3 метою врегулювання питань утримання та розведення диких тварин, які перебувають у стані неволі або в напіввільних умовах, суб'єктами господарювання Міндовкілля прийняло Наказ від 30 вересня 2010 року № 429 [12], яким затвердило Порядок утримання та розведення диких тварин, які перебувають у стані неволі або в напіввільних умовах. Цей Порядок встановлює механізм утримання, використання диких тварин, у тому числі занесених до Червоної Книги України або які $€$ об’єктами регулювання Конвенції про міжнародну торгівлю видами дикої фауни й флори, що знаходяться під загрозою зникнення (далі - CITES), у неволі або в напіввільних умовах, визначає права й обов'язки власників диких тварин, а також контроль у цій сфері.

$\mathrm{Te}$, що цей Порядок затверджений лише наказом Міндовкілля, дещоприменшуєавторитетність, контроль та якість виконання врегульованих таким нормативно-правовим актом приписів щодо охорони й належного утримання диких тварин.

Відповідно до п. 3.1. цього Порядку існують три основні умови, які допускають утримання диких тварин у неволі, а саме, якщо:

1) створені умови, що відповідають їх біологічним, видовим та індивідуальним особливостям;

2) дотримані вимоги, встановлені Законом України «Про захист тварин від жорстокого поводження»;

3) наявні документи, що підтверджують законність набуття дикої тварини.

Догляд за тваринами має здійснюватися під керівництвом кваліфікованих спеціалістів у такий спосіб, щоб уникнути дискомфорту, стресів і травмування тварин.

Разом із тим законодавство України не містить вимог щодо професійно-освітніх характеристик осіб (у тому числі власників), які здійснюють поводження з тваринами, тому було б доцільним затвердити на законодавчому рівні вимоги щодо обов'язкового мінімуму знань для таких осіб. Природно, що такі вимоги повинні стосуватися 
власників тварин, які використовують їх у господарській діяльності або утримують значну кількість особин тварин [13, с. 277].

Дикі тварини повинні утримуватися у вольєpax, клітках або інших приміщеннях, норми площі яких не можуть бути менші, ніж мінімальні норми згідно з додатком до цього Порядку. Наприклад, мінімальна площа для утримання та розведення ведмежих (із розрахунку на одну особину) становить 30 м $^{2}$ площі й 3 метри висоти у вольері.

Контроль за дотриманням законодавства в процесі утримання та розведення диких тварин, які перебувають у стані неволі або в напіввільних умовах, здійснює Державна екологічна інспекція України та її територіальні органи.

Так, відповідно до підпункту д) п. 4 Положення про Державну екологічну інспекцію України [14] Держекоінспекція здійснює державний нагляд (контроль) за додержанням територіальними органами центральних органів виконавчої влади, місцевими органами виконавчої влади, органами місцевого самоврядування в частині здійснення делегованих їм повноважень органів виконавчої влади, підприємствами, установами й організаціями незалежно від форми власності й господарювання, громадянами України, іноземцями й особами без громадянства, а також юридичними особами - нерезидентами вимог законодавства про раціональне використання, відтворення та охорону об'єктів тваринного світу, зокрема щодо: регулювання чисельності диких тварин; використання та відтворення рідкісних і таких, що перебувають під загрозою зникнення, видів тварин, занесених до Червоної книги України; утримання та розведення диких тварин, які перебувають у стані неволі або в напіввільних умовах; наявності документів, що підтверджують законність набуття диких тварин, у тому числі тих, що занесені до Червоної книги України; наявності дозвільних документів на утримання та розведення диких тварин; захисту диких тварин від жорстокого поводження; законності набуття в приватну власність об'єктів тваринного світу.

Таким чином, у разі недотримання власником тварини (зокрема бурого ведмедя) умов щодо їі утримання Держекоінспекція має відповідні повноваження для реагування на такі порушення. Серед планів перевірок навряд чи будуть такі підприємства, як ресторан чи відпочинковий комплекс, тому для оперативного реагування на порушення в цій сфері єдиним шляхом є, наприклад, звернення фізичної особи (фізичних осіб) про порушення, що спричинило шкоду їі (іхнім) правам, законним інтересам, життю чи здоров'ю, навколишньому природному середовищу відповідно до ч. 1 ст. 6 Закону України «Про основні засади державного нагляду (контролю) у сфері господарської діяльності» [15].
У ч. 3 ст. 88-1 КУпАП передбачена відповідальність за порушення правил утримання диких тварин у неволі або в напіввільних умовах. Саме за цією статтею в єдиному державному реєстрі судових рішень можна знайти справи про неналежне утримання ведмедів у неволі. Санкція статті передбачає штраф від 51 до 850 гривень (приблизно від 1,5 до 25 EUR) із конфіскацією об'єктів тваринного або рослинного світу чи без такої. Об'єктивну сторону такого правопорушення становить зазвичай недотримання мінімальних норм розмірів вольеру й відсутність дозволу на утримання тварини. Якщо розміри вольеру - це виключна компетенція та відповідальність власника тварини, то 3 наявністю дозволу на утримання тварин у неволі, що видається Міндовкілля, ситуація складніша.

Як вже зазначалося вище, законодавство України передбачає обов'язковість отримання такого дозволу й зазначає, що видача цього документа закріплена за Міндовкілля, проте сама процедура отримання такого дозволу не прописана міністерством. Виникає казус, коли навіть доброчесний власник звертається до Міндовкілля за отриманням дозволу, а йому його не видають через відсутність процедури й неузгодженість законодавства.

Приклад такої прогалини в законодавстві можна спостерігати, зокрема, в рішенні Ленінського районного суду м. Миколаєва від 24 вересня 2013 року, справа № 3/489/2021/13 [16], де вказується, що під час перевірки діяльності Комунальної установи «Миколаївський зоопарк» встановлено, що комунальною установою утримуються дикі тварини, а саме: ведмідь камчатський бурий (дві особи), ведмідь гімалайський білогрудий, ведмідь губач, за такої умови, що дозвіл на утримання диких тварин у неволі відсутній. Комунальна установа «Миколаївський зоопарк» 20 серпня 2013 року за вих. № 278 звернулося до департаменту охорони природних ресурсів Міністерства екології та природних ресурсів України щодо роз'яснення процедури й можливості отримання дозволів на утримання диких тварин у неволі, в умовах зоопарку, зокрема ведмедів. На що вказана установа дала роз'яснення, що порядок видачі таких дозволів ще не затверджений у зв'язку з невідповідністю Закону України «Про захист тварин від жорстокого поводження», Закону України «Про тваринний світ», Закону України «Про дозвільну систему у сфері господарської діяльності» .

У рішенні Кремінського районного суду в Луганській області від 24 липня 2017 року, справа № 414/1249/17 [17] вбачається ідентична ситуація. 22 червня 2017 року об 11.10 у ході проведення позапланової перевірки на товаристві з обмеженою відповідальністю «Пінта-Кремінський пивоварний завод» було виявлено бурого ведмедя в клітці, відповідальною особою за якого згідно з наказом по підприємству є ОСОБА_2 (працює на 
посаді юрисконсульта). Ведмідь на час перевірки утримувався 3 порушенням правил утримання диких тварин у неволі. ОСОБА_2 свою провину визнав частково. Зазначив, що наказом по підприємству вчинено ряд дій відповідно до припису екологічної інспекції щодо покращення умов утримання тварини, а саме ведмедя, та доведення їх до стандартів, передбачених законодавством. Щодо отримання дозволу на утримання тварини вказав, що він намагався його отримати, проте існує законодавча неузгодженість із цього питання, про що свідчить офіційний лист Міністерства екології та природних ресурсів України як відповідь на його звернення.

Таким чином, виникає ситуація, коли навіть у разі бажання добросовісно отримати обов'язковий дозвіл на утримання ведмедя в неволі уповноважене Міністерство не надає відповідні адміністративні послуги, тому адміністративне правопорушення матиме безперервний характер.

Разом із тим мізерна санкція ст. 88-1 КУпАП не зможе налякати ані добросовісного власника тварини, ані постійного порушника в цій сфері. Чи дає тоді якийсь результат притягнення винних осіб до адміністративної відповідальності й чи можна тут говорити про виконання завдання КУпАП та основних правових функцій адміністративного законодавства, в разі якщо суди в цих справах змушені стати на бік винних осіб і призначати мінімальний штраф у розмірі 51 гривні? Враховуючи такий стан речей, чи можна говорити про належний правовий захист диких тварин і дієвість правових механізмів, які є в наявності в контрольних органів? Очевидно, що ні.

Додатковою санкцією вищевказаної статті передбачена можливість конфіскації тварин. Але тут теж виникає багато запитань, а суди взагалі не хочуть братися за таке, бо незрозуміло, що з такими тваринами далі робити та як їх «правильно» конфіскувати, куди їх скеровувати? Якщо Держекоінспекція під час перевірки самостійно не вкаже про необхідність конфіскації тварини, матеріально-технічні засоби для їі транспортування (особливо якщо йдеться про велику дику тварину) й про місце їі подальшого можливого перебування, то суд не застосовуватиме санкцію у вигляді конфіскації.

Тому залишається лише сподіватися на добросовісність власників тварини, виконання ними приписів Держекоінспекції або пошук притулків для добровільної передачі тварини. Знову ж таки, ця ситуація відбиває неефективність чинного законодавства щодо захисту довкілля.

Позитивну практику у сфері реабілітації та захисту бурих ведмедів мають не стільки державні структури, скільки ведмежі притулки в Україні. У 2011 році на території Національного природного парку «Синевир» вперше запрацював $\mathrm{Pe}$ - абілітаційний центр для бурих ведмедів, що займає площу 12 га. Під захист сюди потрапляють тварини, які зазнали жорстокого поводження чи утримувалися в неволі без відповідних умов. Ведеться також робота по відтворенню природної популяції (в Україні нараховано близько 300 особин) і поглибленню досліджень найбільшого хижака України. Ще один відомий центр порятунку й реабілітації бурих ведмедів «Домажир» діє у Львівській області й створений за підтримки міжнародного благодійного фонду FOUR PAWS, що базується у Відні (Австрія).

Проєкти ведмежих притулків FOUR PAWS в Австрії, Німеччині, Україні, Косово, В'єтнамі, Болгарії та Швейцарії пропонують перевести до природного середовища бурих ведмедів, які утримуються в неволі в жахливих умовах. Тут вони можуть відновити свої природні інстинкти й поводитися природно, як у звичайних умовах, характерних для їх проживання.

Ці притулки зазвичай ведуть переговори з власниками ведмедів (ресторанні комплекси, бази відпочинку, цирки тощо) щодо добровільної передачі тварин на баланс ведмежих притулків. Також виникає запитання, з ким вести такі переговори, хто ж є власником ведмедя, якщо в ресторанів і баз відпочинку відсутні документи на утримання диких тварин (через відсутність процедури надання такого дозволу). А шляхів для примусового вилучення таких тварин натепер фактично не існує.

Незаконне або неналежне утримання диких тварин, зокрема ведмедів, може призвести до завдання шкоди третім особам. У такому випадку потрібно керуватися цивільним законодавством, а в разі завдання шкоди здоров'ю звертатися в поліцію із заявою про вчинення злочину в залежності від отриманих ушкоджень.

Законодавство України покладає відповідні обов'язки на власників тварин. Дикі тварини це тварини, природним середовищем існування яких є дика природа, в тому числі ті, які перебувають у неволі чи напіввільних умовах (ст. 1 Закону України «Про захист тварин від жорстокого поводження»), утримання яких вважається діяльністю, пов'язаною з підвищеною небезпекою (ч. 1 ст. 1187 Цивільного кодексу України). Шкода, завдана джерелом підвищеної небезпеки, відшкодовується особою, яка на відповідній правовій підставі (право власності, інше речове право, договір підряду, оренди тощо) володіє транспортним засобом, механізмом, іншим об'єктом використання, зберігання або утримання якого створює підвищену небезпеку. Особа, яка здійснює діяльність, що є джерелом підвищеної небезпеки, відповідає за завдану шкоду, якщо вона не доведе, що шкоди було завдано внаслідок непереборної сили або умислу потерпілого. 
1 квітня 2020 року на сайті Міністерства захисту довкілля та природних ресурсів України було оприлюднено Проєкт постанови Кабінету Міністрів України «Про затвердження Порядку видачі дозволів на спеціальне використання об'єктів тваринного світу». Цей документ має на меті визначити процедуру видачі, відмови у видачі, переоформлення, анулювання юридичним, фізичним особам - підприємцям, фізичним особам (далі користувач) дозволів на спеціальне використання об'єктів тваринного світу.

Дозволи згідно з проєктом видаватимуться на підставі заяви, в якій зазначаються, зокрема, назва виду й роду об'єктів тваринного світу латинською та українською мовами, а також заплановані обсяги іх використання, обгрунтування потреби в його здійсненні; мета використання; місце й строки використання. У разі здійснення спеціального використання об'єктів тваринного світу з метою отримання прибутку потрібно також подати документи, що засвідчують сплату збору за спеціальне використання об'єктів тваринного світу. Але ця норма не може поширюватися на спеціальне використання (добування, збирання) об'єктів Червоної книги України з метою отримання прибутку, оскільки це заборонено.

Також важливою вимогою в проєкті постанови є подання відомостей про умови утримання тварин, наявність кваліфікованого персоналу, конкретні місця, в які планується здійснювати їх переселення, та засоби транспортування (в разі використання тварин із метою їх утримання та розведення в неволі чи напіввільних умовах або переселення в нові місця перебування) в довільній формі. Адже на практиці власники тварин дуже часто не дотримуються саме умов утримання тварин, а кваліфікований персонал, який має відповідну освіту й навички для поводження з дикими тваринами, взагалі відсутній.

Строк дії дозволу становитиме не більше 12 місяців. Після спливу цього терміну дозвіл необхідно переоформити. Користувач у місячний строк після закінчення строку дії дозволу в письмовій формі подає Міндовкілля звіти про спеціальне використання об'єктів тваринного світу із зазначенням місця, дати, способу їх добування, кількості й інформацію про подальше використання (реалізацію, утримання, зберігання тощо).

У разі необхідності надання порятунку диким тваринам, які зазнають лиха, користувач письмово повідомляє про це Держекоінспекцію із зазначенням місця виявлення дикої тварини й тимчасового її утримання (в разі неможливості надати допомогу дикій тварині без її вилучення з природного середовища) й одночасно подає Міндовкілля лише заяву для отримання дозволу. Ця норма буде корисною для волонтерів, екологів, активістів та інших свідомих громадян, які виявили дику тварину в біді й вирішили їй самотужки допомогти.

Отже, аналіз вимог фауністичного законодавства щодо поводження 3 дикими тваринами й практики його застосування засвідчує існування низки законодавчих прогалин у цій сфері, насамперед стосовно правового забезпечення належного контролю за утриманням диких тварин у неволі й подальшої юридичної долі у випадку порушення вимог щодо їх утримання.

Задля вдосконалення правового регулювання відносин щодо поводження 3 дикими тваринами в Україні необхідно заповнити ці прогалини, зокрема:

1) передбачити порядок вилучення тварин у незаконних власників або злісних правопорушників контрольними органами з належним для цього матеріально-технічним забезпеченням;

2)налагодитикоординаціюміжДержекоінспекцією та реабілітаційними центрами для тварин;

3) встановити вимоги щодо професійно-освітніх характеристик осіб (у тому числі власників), які здійснюють поводження з тваринами;

4) посилити санкції за адміністративні правопорушення у сфері охорони природи й використання природних ресурсів за заподіяння шкоди об’єктам тваринного світу;

5) визначити умови й порядок видачі дозволів на спеціальне використання об'єктів тваринного світу.

\section{Jimepamypa}

1. Цивільний кодекс України : Закон України від 16 січня 2003 року № 435-IV / Верховна Рада України. URL: https://zakon.rada.gov.ua/laws/show/ 435-15\#Text (дата звернення: 15.10 .2020 ).

2. Про тваринний світ : Закон України від 13 грудня 2001 року № 2894-III / Верховна Рада України. URL: https://zakon.rada.gov.ua/laws/show/2894-14\#Text (дата звернення: 15.10.2020).

3. Про захист тварин від жорстокого поводження : Закон України від 21 лютого 2006 року № 3447-IV / Верховна Рада України. URL: https://zakon.rada. gov.ua/laws/show/3447-15\#Text (дата звернення: 15.10.2020).

4. Про внесення змін до деяких законодавчих актів України щодо запровадження гуманного ставлення до тварин : Закон України від 22 червня 2017 року № 2120-VIII / Верховна Рада України. URL: https://zakon.rada.gov.ua/laws/show/2120-19\#Text (дата звернення: 15.10.2020).

5. Про внесення змін до деяких законодавчих актів України щодо виконання Конвенції про охорону дикої флори та фауни і природних середовищ існування в Європі : Закон України від 7 лютого 2017 року № 1832-VIII / Верховна Рада України. URL: https://zakon.rada.gov.ua/laws/show/1832-19\#Text (дата звернення: 15.10.2020).

6. Кримінальний кодекс України : Закон України від 5 квітня 2001 року № 2341-III / Верховна Рада України. URL: https://zakon.rada.gov.ua/laws/show/234114\#Text (дата звернення: 15.10.2020). 
7. Про внесення змін до деяких законодавчих актів України щодо спрощення досудового розслідування окремих категорій кримінальних правопорушень : Закон України від 22 листопада 2018 року № 2617-VIII / Верховна Рада України. URL: https://zakon.rada.gov.ua/laws/show/2617-19\#n404 (дата звернення: 15.10.2020).

8. Кодекс України про адміністративні правопорушення : Закон Української РСР від 7 грудня 1984 року № 8073-X. База даних «Законодавство Украӥни». URL: https://zakon.rada.gov.ua/laws/show/80731-10\# Text (дата звернення: 15.10.2020).

9. Про затвердження Правил любительського і спортивного рибальства та Інструкції про порядок обчислення та внесення платежів за спеціальне використання водних живих ресурсів при здійсненні любительського і спортивного рибальства : Наказ Державного комітету рибного господарства України від 15 лютого 1999 року № 19. База даних «Законодавство України». URL: https://zakon.rada.gov.ua/laws/show/ z0269-99\#Text (дата звернення: 15.10.2020).

10. Про Червону книгу України : Закон України від 7 лютого 2002 року № 3055-III / Верховна Рада України. URL: https://zakon.rada.gov.ua/laws/show/ 3055-14\#Text (дата звернення: 15.10.2020).

11. Про затвердження Правил використання тварин у видовищних заходах : Наказ Мінагрополітики від 13 жовтня 2010 року № 643 / Міністерство аграрної політики та продовольства України. URL: https://zakon.rada.gov.ua/laws/show/z1313-10\#Text (дата звернення: 15.10.2020).

12. Про затвердження Порядку утримання та розведення диких тварин, які перебувають у стані неволі або в напіввільних умовах : Наказ Міндовкілля від 30 вересня 2010 року № 429 / Міністерство захисту довкілля та природних ресурсів України. URL: https://zakon.rada.gov.ua/laws/show/z1384-10\#Text (дата звернення: 15.10.2020).

13. Шеховцов В.В. Правові проблеми запровадження європейських стандартів реалізації права приватної власності на тварин. Університетські наукові запис кu. 2012. № 3. C. 274-278. URL: http://nbuv.gov.ua/ UJRN/Unzap_2012_3_40(дата звернення: 15.10.2020).

14. Про затвердження Положення про Державну екологічну інспекцію України : Постанова Кабінету Міністрів України від 19 квітня 2017 р. № 275 / Кабінет Міністрів України. URL: https://zakon.rada.gov. ua/laws/show/275-2017-\% D0\% BF \#Text (дата зверненHя: 15.10 .2020$)$.

15. Про основні засади державного нагляду (контролю) у сфері господарської діяльності : Закон України від 5 квітня 2007 року № 877-V / Верховна Рада України. URL: https://zakon.rada.gov.ua/laws/show/ 877-16\#Text (дата звернення: 15.10.2020).
16. Постанова Ленінського районного суду м. Миколаєва від 24 вересня 2013 року у справі № 3/489/2021/13. ЄӘиний державний реєстр судових справ. URL: http://reyestr.court.gov.ua/Review/ 34002399 (дата звернення: 15.10.2020).

17. Постанова Кремінського районного суду в Луганській області від 24 липня 2017 р. у справі № 414/1249/17. Єәиний державний реєстр судових справ. URL: http://reyestr.court.gov.ua/Review/ 67876994 (дата звернення: 15.10.2020).

\section{Анотація}

Шпарик $H$. $Я$. Проблеми та перспективи правового регулювання поводження з дикими тваринами в Україі. - Стаття.

У статті розглянуто проблемні аспекти правового регулювання поводження 3 дикими тваринами. Проаналізовано останні внесені зміни в законодавство України в цій сфері, а саме Закон України «Про внесення змін до деяких законодавчих актів України щодо запровадження гуманного ставлення до тварин» і Закон України «Про внесення змін до деяких законодавчих актів України щодо виконання Конвенції про охорону дикої флори та фауни і природних середовищ існування в Європі». Ці закони встановили жорсткіші види покарання за неналежне або ж жорстоке поводження 3 тваринами, проте розв'язали не всі проблемні питання в галузі. Зокрема, до статті 88-1 Кодексу України про адміністративні правопорушення, яка передбачає відповідальність за порушення порядку придбання чи збуту об'єктів тваринного або рослинного світу, правил утримання диких тварин у неволі або в напіввільних умовах, зміни не вносилися, а розмір санкції починається зі штрафу в розмірі від трьох неоподатковуваних мінімумів доходів громадян.

У статті проаналізовано практичні випадки, коли особа утримує бурого ведмедя в приватній власності. Розглянуто основні нормативні вимоги для правомірного утримання та розведення диких тварин, які перебувають у стані неволі або в напіввільних умовах. Досліджено засади спеціального використання (добування, збирання) об’єктів Червоної книги України, до яких відноситься бурий ведмідь.

Окреслено правові засади для здійснення контролю Державною екологічною інспекцією України за дотриманням законодавства в процесі утримання та розведення диких тварин, які перебувають у стані неволі або в напіввільних умовах.

Зображено основні проблеми й запропоновано шляхи для вдосконалення правового регулювання відносин щодо поводження $з$ дикими тваринами в Україні.

Ключові слова: тваринний світ, дикі тварини, захист тварин від жорстокого поводження, юридична відповідальність, спеціальне використання об'єктів тваринного світу. 


\section{Summary}

Shparyk N. Ya. Problems and prospects of legal regulation of wild animals' treatment in Ukraine. - Article.

The article studies the problematic aspects of the legal regulation of the treatment of wild animals. The latest amendments to the legislation of Ukraine in this area are analyzed, namely, the Law of Ukraine "On Amendments to Certain Legislative Acts of Ukraine on the Introduction of Humane Treatment of Animals" and the Law of Ukraine "On Amendments to Certain Legislative Acts of Ukraine on Implementation of the Berne Convention on the Conservation of European Wildlife and Natural Habitats". These laws set stricter penalties for cruelty to animals or cruel treatment but did not address all issues in this area. In particular, Article 88-1 of the Code of Ukraine on Administrative Offenses, which provides for liability for violation of the order of acquisition or sale of objects of fauna and flora, the rules of keeping wild animals in captivity or semi-free conditions, has not been amended, and the sanction begins with a fine of only three non-taxable minimum incomes.

The article analyzes practical cases when a person keeps a brown bear as a private property. The main regulatory requirements for the lawful keeping and breeding of wild animals that are in captivity or in semi-free conditions are considered. The principles of special use (extraction, collection) of objects of the Red Book of Ukraine, which include the brown bear, have been studied.

The legal bases for control by the State Environmental Inspection of Ukraine over the observance of the legislation during the keeping and breeding of wild animals, which are in a state of captivity or in semi-free conditions, are outlined.

The main problems are reflected and ways of improvement of legal regulation of relations with the treatment of wild animals in Ukraine are suggested.

Key words: wildlife, wild animals, protection of animals from cruel treatment, legal liability, special use of objects of fauna. 